Ekonomia - Wroclaw Economic Review 27/1 (2021)

Acta Universitatis Wratislaviensis

No 4066

https://doi.org/10.19195/2658-1310.27.1.3

Patrycja Guzikowska

ORCID: 0000-0002-1705-6946

Szkoła Główna Handlowa w Warszawie

guzikowska.patrycja@gmail.com

\title{
Cykl koniunkturalny w Turcji w latach 2005-2020 — interpretacja austriackiej szkoły ekonomii
}

Artykuł nadesłany: 10.06.2021; artykuł zaakceptowany: 28.08.2020

Kody klasyfikacji JEL: B53, E32, E58

Keywords: Turkey, business cycle, Austrian School of Economics

\begin{abstract}
The business cycle in Turkey (2005-2020) - an interpretation of the Austrian School of Economics

Turkey was hit by the recession, defined in a classic way (as negative real GDP growth lasting at least two quarters), three times over the discussed period. The main goal of the central bank of Turkey is to keep inflation as close as possible to the inflation target. The use of the interest rate as a tool to stabilize the economic situation is therefore limited. The country has experienced periods of high inflation which was not temporary, but long-term. Using the approach appropriate to the Austrian School of Economics, the article analyzes the behavior of the Turkish economy in 2005-2020. In the discussed time horizon, two phases of the business cycle have been identified according to the Austrian School of Economics - the first from 2005 to the first quarter of 2014, and the second from the second quarter of 2014 to 2020 . It can be assumed that the Turkish economy will enter the third phase of the business cycle in the near future, although it is difficult to determine when it will happen.
\end{abstract}

\section{Wstęp}

Analizy, które dotyczą kryzysów występujących współcześnie, koncentrują się wokół kryzysu z lat 2007-2009. Wybuch pandemii COVID-19 w roku 2020 niewątpliwie uderzył w gospodarkę światową, ale ponieważ jeszcze się nie skończy- 
ła, nie sposób w tym momencie ocenić głębokości i przyszłych skutków recesji, która z dużym prawdopodobieństwem dotknie wiele krajów.

Celem artykułu jest empiryczna weryfikacja austriackiej teorii cyklu koniunkturalnego dla go-spodarki Turcji w latach 2005-2020. W pracy zastosowano następujące metody badawcze: analizę piśmiennictwa oraz metodę statystyczną.

Analiza wskaźników makroekonomicznych pozwoli odpowiedzieć na pytanie, czy w Turcji wystąpiła recesja zgodna z austriacką interpretacją cyklu. Jeśli odpowiedź na to pytanie będzie twierdząca, porównany zostanie moment czasowy jej wystąpienia $\mathrm{z}$ tradycyjnie definiowaną recesją. W przeciwnym wypadku — na podstawie analizy danych — wskazane zostanie, w jakiej fazie cyklu aktualnie znajduje się gospodarka turecka. Wstępem do identyfikacji faz cyklu według szkoły austriackiej jest interpretacja zmienności podstawowych wskaźników makroekonomicznych i wskazanie okresów klasycznie definiowanej recesji.

\section{Podstawowe zagadnienia związane z austriacką teorią cyklu koniunkturalnego}

Rozpoczęcie analizy przebiegu kryzysu w Turcji wymaga uprzednio wyjaśnienia austriackiej teorii cyklu koniunkturalnego. Trzy najistotniejsze pojęcia niezbędne do zrozumienia tej teorii to: teoria kapitału, preferencja czasowa oraz zagregowana struktura produkcji.

Teoria kapitału sprowadza się do podziału dóbr na dwa rodzaje: kapitałowe i konsumpcyjne. Różnią się one czasem wykorzystywania i odległością produkcji danego dobra od etapu produkcji dóbr konsumpcyjnych. Dobra konsumpcyjne są wykorzystywane w krótkim okresie i są to dobra pierwszego rzędu, co oznacza, że trafiają bezpośrednio do nabywców. Dobra kapitałowe, które są wykorzystywane w średnim i długim okresie, ,powstają w wyniku akumulacji trzech elementów: surowców naturalnych, pracy i czasu" (Huerta de Soto, 2010, 73). Odległość ich produkcji od produkcji dóbr konsumpcyjnych jest zatem większa niż samych dóbr konsumpcyjnych. Drugim istotnym pojęciem jest subiektywna preferencja czasowa. Preferencja czasowa pokazuje - w dużym uproszczeniu - czy osoba woli konsumować dziś, czy w przyszłości, a także jak różni się użyteczność konsumpcji danego dobra dzisiaj od tej, jaką konsument osiągałby z konsumpcji danego dobra w przyszłości. Osoba, która ma wysoką preferencję czasową, potrzebuje wysokiej „rekompensaty” za odłożenie swojej konsumpcji w czasie. Sprowadza się to do większej wartości dóbr teraźniejszych od dóbr przyszłych, a zaspokojenie swojej potrzeby konsumpcyjnej natychmiast bądź w niedalekiej przyszłości jest bardziej cenione niż w przyszłości dalszej, o czym pisał Mises $(2011,411)$. Połączenie dwóch omawianych wcześniej pojęć pozwala na wprowadzenie terminu naturalnej stopy procentowej, którą określa się „stosunek wartości przypisywanej zaspokojeniu potrzeby w najbliższej przyszłości 
do wartości przypisywanej jej zaspokojeniu w odległych okresach przyszłości. W gospodarce rynkowej wyraża się on dyskontowaniem dóbr przyszłych względem dóbr teraźniejszych. Nie jest ceną, lecz stosunkiem cen towarów" (Mises 2011, 446-447). Natomiast rynkowa stopa procentowa jest naturalną stopą procentową, która została powiększona o premię za ryzyko (związane z daną transakcją) oraz zmieniona (powiększona lub pomniejszona) o premię z oczekiwanej inflacji lub deflacji (Huerta de Soto, 2011, 216). Wspomniana odległość etapu produkcji danego dobra od etapu produkcji dóbr konsumpcyjnych została zastosowana w koncepcji zagregowanej struktury produkcji. Pozwala ona na przestawienie przepływu środków pieniężnych od właścicieli dóbr konsumpcyjnych do właścicieli czynników produkcji. Na rysunku 1 przedstawione zostały kolejne etapy produkcji — od surowców, przez dobra produkcyjne, hurtowe, aż do dóbr konsumpcyjnych.

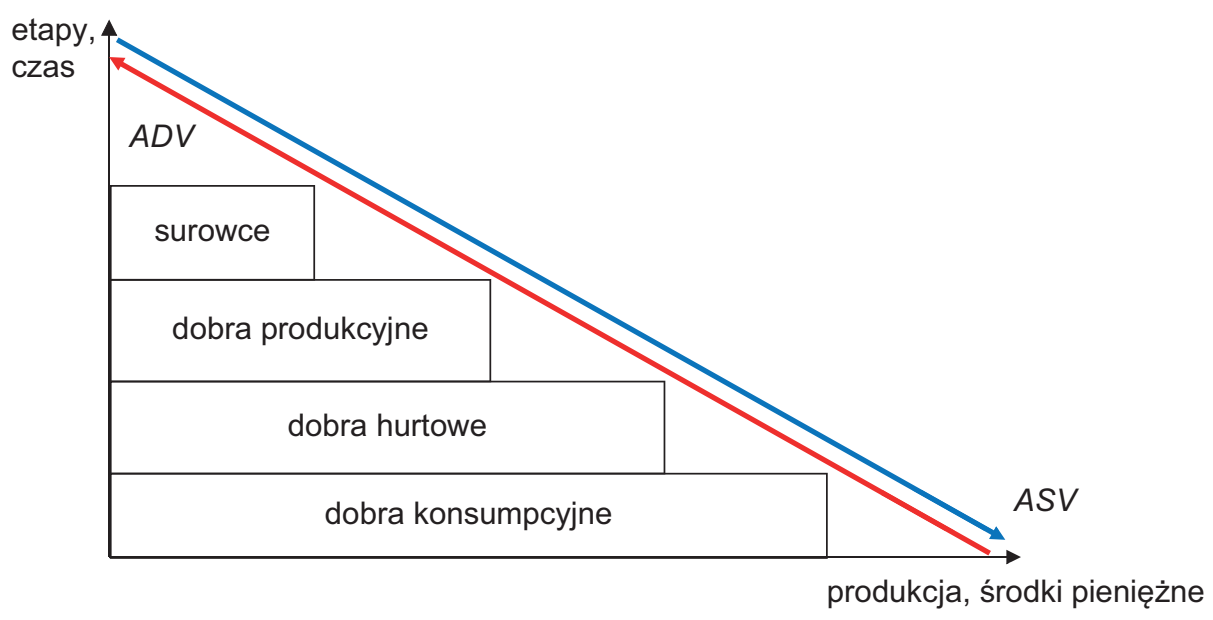

Rysunek 1. Koncepcja prostej struktury produkcji

Źródło: opracowanie własne na podstawie Skousen, M. (2011). Struktura produkcji. Giełda, kapitat, konsumpcja. Warszawa: Fijorr Publishing.

Na rysunku zostały również zaznaczone wektory: ASV — wektor zagregowanej podaży (prezentujący przepływ dóbr), oraz ADV — wektor zagregowanego popytu (przepływ środka pieniężnego), które w gospodarce jednostajnie funkcjonującej są sobie równe.

Koncepcja struktury produkcji przypisywana jest tradycyjnie Hayekowi (1931 [2014]). Za pomocą trójkątów dokonał on integracji koncepcji dóbr różnych rzędów autorstwa Mengera i okrężności (różnej długości w czasie) metod produkcji autorstwa Böhm-Bawerka. Struktura produkcji określana jest zatem dwoma wymiarami - czasem niezbędnym do wytworzenia określonego rodzaju dóbr konsumpcyjnych (długość struktury produkcji) oraz komplikacją (złożonością) procesu produkcji (szerokość struktury produkcji). 
W cyklu koniunkturalnym struktura produkcji ulega zmianie, co jest następstwem zmiany stopy preferencji czasowej. Struktura produkcji ulega wydłużeniu, gdy maleje stopa preferencji czasowej — w tej sytuacji większość środków pieniężnych przeznaczana jest na inwestycje, nie zaś na konsumpcję. W przeciwnym przypadku, to jest gdy struktura produkcji ulega skróceniu, oznacza to, że większa część środków pieniężnych przeznaczana jest na wydatki konsumpcyjne (a mniejsza na wydatki inwestycyjne). Szeroko zmiany te omawia i wykorzystuje do opisu działania gospodarki Garrison (2001).

\section{Analiza teorii monetarnej i działania banku centralnego}

Hayek wskazywał istniejące wciąż w teorii monetarnej błędy metodologiczne i zgubny dla przeciętnego obywatela brak wiedzy teoretycznej, który umożliwia rządzącym wpływanie na mechanizm rynkowy. Interwencje te mają skutki uboczne (Huerta de Soto, 2010, 269-270). Żeby je zrozumieć, należy odwołać się do myśli Rothbarda (2010, 4), który pisał: „wahania ogólnogospodarcze muszą się rozprzestrzeniać za pośrednictwem powszechnego środka wymiany, jakim jest pieniądz. Pieniądz stanowi ogniwo łączące wszystkie sfery działalności gospodarczej”. Pieniądz, a konkretnie jego niewłaściwe użycie, jest więc przyczyną powstawania kryzysów. Natomiast podmiotami odpowiedzialnymi za niewłaściwe używanie pieniądza są banki komercyjne, odpowiadające za nadmierną ekspansję kredytową. Mogą one natomiast pozwolić sobie na prowadzenie takiej ekspansji z dwóch istotnych powodów: braku wymogu zachowywania stuprocentowej rezerwy oraz istnienia banku centralnego (który dla banków komercyjnych jest tak zwanym pożyczkodawcą ostatniej instancji). Zerwanie z wymogiem rezerwy stuprocentowej, które było przywilejem otrzymanym przez banki komercyjne od rządu, prowadzi do sztucznego kreowania pieniądza. Jeżeli banki miałyby obowiązek zachowywania rezerwy stuprocentowej, musiałyby przechowywać depozyt swojego klienta do czasu, aż sam się po niego zgłosi. Współcześnie tak się jednak nie dzieje, gdyż bank komercyjny może zachować jedynie część depozytu (rezerwę cząstkową będącą obowiązkowym procentem zdeponowanej kwoty), resztę zaś pożycza innemu klientowi na określony procent. Rothbard $(2007,109)$ zauważa: „Im mniejszy ułamek stanowi rezerwa, tym większa ilość nowych pieniędzy, które tworzą jak gdyby piramidę odwróconą. [...] Banki komercyjne - a konkretnie banki stosujące rezerwy cząstkowe - tworzą pieniądze z niczego".

Przedstawiciele szkoły austriackiej zwracają uwagę na fakt, że środki zdeponowane w banku nie są własnością banku — bank, pożyczając te środki, ,przywłaszcza" sobie cudzą własność (Huerta de Soto, 2010, 276). Jeżeli deponenci odkryją, że bank nie jest zdolny do wypłaty wszystkich zdeponowanych tam pieniędzy, zaczyna on mieć problemy z płynnością finansową. Istnieje jednak po- 
życzkodawca ostatniej szansy — bank centralny, który w przypadku tego typu problemów może pomóc bankowi komercyjnemu przez zapewnienie mu koniecznej płynności (Huerta de Soto, 2010, 278). Bank centralny, pożyczając środki bankom komercyjnym, powoduje utrzymanie niewypłacalnych instytucji finansowych, które w systemie wolnej bankowości niewypłacalność z pewnością przypłaciłyby bankructwem. Istnienie pożyczkodawcy ostatniej instancji sprzyja również pokusie nadużycia — banki komercyjne mogą podejmować bardziej ryzykowne działania, licząc na to, że w przypadku niewypłacalności uratuje je bank centralny.

\section{Mechanizm działania cyklu koniunkturalnego w ASE}

Punktem wyjścia do analizy będzie makroekonomiczna równowaga na rynku funduszy pożyczkowych. W punkcie równowagi krzywa podaży (to jest oszczędności) przecina się z krzywą popytu (to jest inwestycji). W równowadze zaobserwować można równość naturalnej i rynkowej stopy procentowej (rysunek 2).

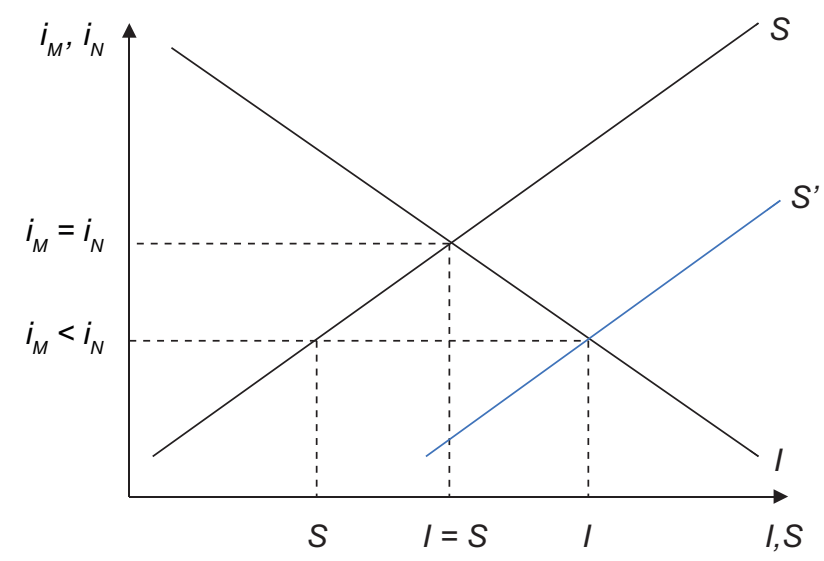

Rysunek 2. Pierwotna równowaga na rynku funduszy pożyczkowych i jej zaburzenie

Źródło: opracowanie własne.

Obniżenie rynkowej stopy procentowej poniżej równowagi (a więc poniżej naturalnej stopy procentowej) powoduje zwiększenie popytu na fundusze pożyczkowe (na rynku obserwuje się zwiększoną podaż, która wynika z dodruku lub ekspansji kredytowej).

W pierwszej fazie austriackiej teorii cyklu obniżenie stopy procentowej daje przedsiębiorstwom bodziec do zwiększenia inwestycji. Przedsiębiorcy podejmują złe decyzje, inwestując w przedsięwzięcia, które tylko pozornie są rentowne. Inwestycje, ze względu na swą długoterminowość, są wrażliwe na zmiany stopy pro- 
centowej. Skutkiem działania ekspansji kredytowej w pierwszej kolejności będzie wzrost cen pierwotnych czynników produkcji - pracy i zasobów naturalnych.

W drugiej fazie produkujący dobra wyższego rzędu potrzebują siły roboczej — oferują pracownikom wyższe wynagrodzenia i zaczynają zatrudniać więcej pracowników. Z sektora niższego rzędu pracownicy przepływają do sektora produkcji dóbr wyższych rzędów. Rośnie popyt konsumpcyjny, co jest następstwem wyższych wynagrodzeń i zmieniającej się preferencji czasowej (pracownicy, osiągając większy dochód, cenią konsumpcję bieżącą bardziej niż oszczędzanie). Rosnący popyt konsumpcyjny jest efektem natychmiastowym, na który nie może odpowiedzieć podaż. Producenci inwestowali bowiem w przedsięwzięcia długoterminowe, co powoduje znaczne wydłużenie się czasu produkcji. Na tym etapie najwyższa dynamika cen powinna być obserwowana w sektorze produkcji dóbr pośrednich (w tym kapitałowych).

W fazie trzeciej ceny dóbr konsumpcyjnych zaczynają wzrastać, a dynamika tego wzrostu jest największa (w stosunku do pozostałych dóbr). Wzrasta rentowność tych przedsiębiorstw, które posiadają czynniki produkcji zaangażowane w wytwarzanie dóbr konsumpcyjnych. Część przedsiębiorstw już teraz widzi, że wcześniejsze decyzje inwestycyjne były nietrafione, i zmienia je, przenosząc środki finansowe do produkcji dóbr konsumpcyjnych. Jednocześnie obserwuje się spadek wynagrodzenia czynnika pracy, co powoduje zamianę relatywnie droższego czynnika kapitału na tańszą pracę (,efekt Ricarda”). Przedsiębiorstwa mające już pełną świadomość, że inwestycje, które wcześniej uznali za rentowne, były błędem, mają trudność z zakończeniem trwających projektów. Zaczynają konkurować między sobą o pożyczki, co powoduje wzrost stopy procentowej. Dodatkowe koszty zrealizowania inwestycji nie odstraszają jednak inwestorów od ich realizacji i są oni gotowi wziąć pożyczkę nawet przy wyższej stopie procentowej. Przedsiębiorcy ci wciąż liczą na poprawę sytuacji. Wzrost oprocentowania kredytów jest spowodowany koniecznością zrekompensowania strat poniesionych przez banki (część nierentownych przedsięwzięć już upadła, a inwestorzy nie byli w stanie spłacić długu). Rosnąca stopa procentowa generuje straty przedsiębiorców, działających na odległych etapach produkcji, a bank komercyjny nie chce udzielać takim firmom kredytów. Ekspansja kredytowa zostaje ograniczona - warunki wzięcia kredytu są bardziej rygorystyczne, a wypłacane kwoty mniejsze. Banki, które dostatecznie wcześnie nie zaprzestały swojej ekspansywnej działalności kredytowej, upadają. Ograniczenia w dostępie do kredytów powodują, że kolejne nierentowne przedsięwzięcia upadają, a zatrudnienie jest ograniczane.

W fazie czwartej (fazie depresji) obserwowane jest zmniejszenie popytu konsumpcyjnego, który z kolei pociąga za sobą spadek cen. Maleją również oczekiwania inflacyjne i rynkowa stopa procentowa. Rynek dóbr kapitałowych osiąga równowagę, jest ona jednak inna niż ta sprzed kryzysu (rynkowa stopa procentowa będzie wyższa niż naturalna). Rothbard $(2008,414)$ uważa, że ta faza jest w rze- 
czywistości „fazą zdrowienia gospodarki”, gdyż faza depresji pozwala na wyeliminowanie tych przedsięwzięć, które od początku były nierentowne.

\section{Zmiana wybranych wskaźników makroekonomicznych w Turcji}

Podstawową kwestią do rozstrzygnięcia jest to, czy w Turcji w omawianych latach występowała recesja, którą możemy zdefiniować jako spadek realnego PKB utrzymujący się przez co najmniej dwa kwartały. W przypadku Turcji taką sytuację możemy zaobserwować w latach 2007, 2008, 2009 i 2018 (rysunek 3).

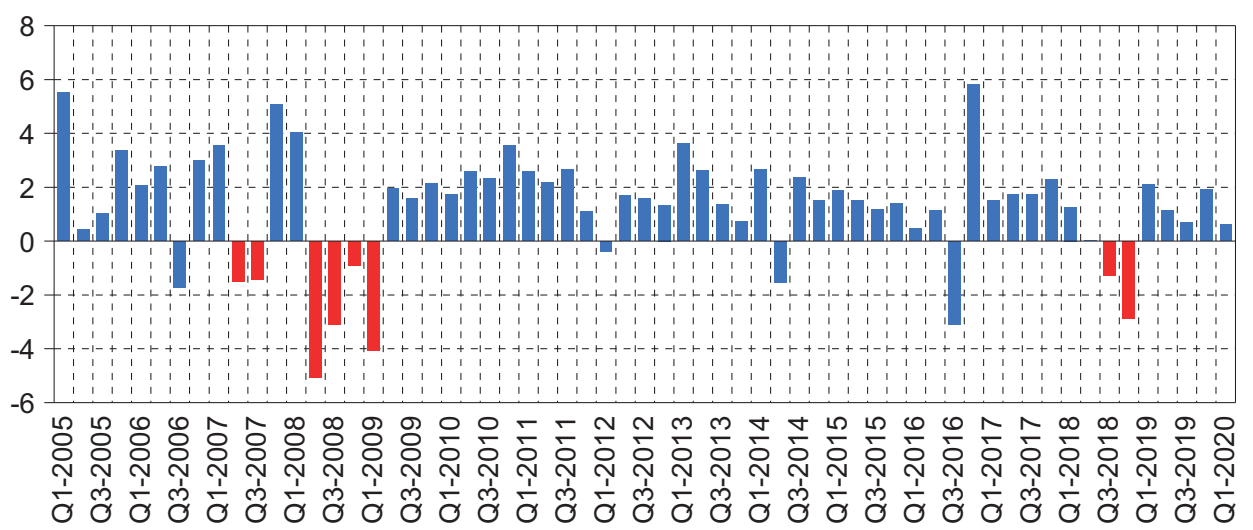

Rysunek 3. Stopa wzrostu realnego PKB w okresie Q1-2005-Q1-2020 (kwartał do poprzedniego kwartału, dane odsezonowane [\%])

Źródło: OECD.

W przypadku roku 2007 recesję zidentyfikowano w kwartałach II i III. Kolejna recesja może zostać zdiagnozowana w: II, III, IV kwartale 2008 roku i I kwartale 2009 roku. W 2018 roku ujemna dynamika realnego PKB odnotowana została w III i IV kwartale. Każdy z tych okresów objąć można klasyczną definicją recesji (spadek realnego PKB trwający co najmniej dwa kwartały z rzędu). Możemy zaobserwować, że kiedy Turcja wychodziła z pierwszej recesji (w IV kwartale 2007 i I kwartale 2008 roku dynamika realnego PKB była już dodatnia), w jej gospodarkę uderzył światowy kryzys finansowy (w II kwartale 2008 roku).

Drugim istotnym wskaźnikiem jest poziom podstawowej stopy procentowej. Warto na początku zaznaczyć, że turecki bank centralny prowadzi politykę, wykorzystując strategię bezpośredniego celu inflacyjnego, który jest ustalany przez bank centralny w porozumieniu z rządem w perspektywie trzyletniej (BCRT, 2012, 11). W latach 2002-2005 bank centralny prowadził politykę niejawnego celu inflacyjnego. Od 2006 roku polityka bezpośredniego celu inflacyjnego jest prowadzona oficjalnie. Ustawa o banku centralnym z 2001 roku określa, że bank 
centralny jest zobowiązany do zapewnienia stabilności cen i wspierania polityki rządu w zakresie wzrostu gospodarczego pod warunkiem, że polityka ta nie stoi w konflikcie z celem głównym banku centralnego. Aby to osiągnąć, bank centralny prowadzi w sposób uznaniowy dyskrecjonalną politykę pieniężną i wybiera narzędzia, jakie w tym celu stosuje (ma zatem niezależność w odniesieniu do używanego instrumentarium). Gubernatora banku powołuje na czteroletnią kadencję prezydent Turcji, z możliwością powtórnego powołania. Może on być jednak odwołany przed upływem kadencji.

Zidentyfikowane zostało pewne opóźnienie w reakcji banku centralnego na zmianę realnego PKB, gdyż działanie za pomocą stopy procentowej w sytuacji recesji jest możliwe wyłącznie kiedy inflacja jest zbliżona do celu inflacyjnego (lub niższa), ponieważ podstawowym celem banku centralnego jest stabilność cen (rysunek 4).

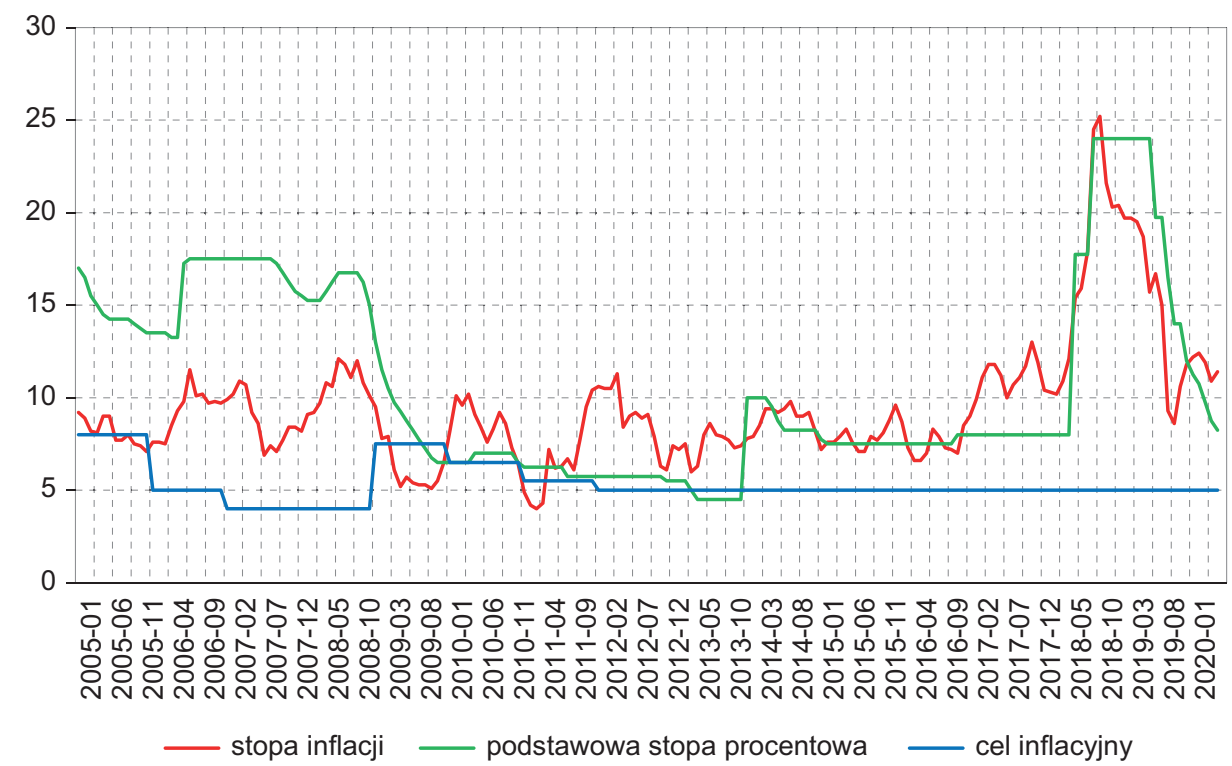

Rysunek 4. Poziom inflacji, podstawowej stopy procentowej i celu inflacyjnego (\%)

Źródło: Eurostat, Bank for International Settlements, Bank Centralny Republiki Turcji.

W pierwszej zidentyfikowanej recesji (kwiecień-wrzesień 2007) inflacja malała z poziomu 10,9\% (kwiecień) do poziomu 7,1\% (wrzesień). Wciąż znajdowała się jednak powyżej celu inflacyjnego, który wynosił 4\%. Natomiast stopa procentowa od lipca 2006 pozostawała na poziomie 17,5\% (co było reakcją banku centralnego na wysoką inflację) aż do sierpnia 2007 roku. Pod koniec III kwartału (w którym odnotowano ujemną dynamikę realnego PKB), we wrześniu, zdecydowano się na obniżenie stopy procentowej. Obniżki trwały do kwietnia 2008 roku, kiedy to stopa procentowa wynosiła 15,25\%. Mogło być to opóźnioną reakcją na 
recesję II i III kwartału 2007. Na skutek obniżania stopy procentowej ponownie zaczęła wzrastać inflacja (w kwietniu 2008 roku wynosiła 9,7\%). Bank centralny podjął decyzję o ponownym podwyższaniu stopy procentowej, począwszy od maja 2008 roku, co z kolei zbiegło się w czasie z uderzeniem światowego kryzysu finansowego w Turcję. Recesja trwała od kwietnia 2008 roku do marca 2009, natomiast stopy procentowe, podwyższane do lipca 2008 roku (do poziomu 16,75\%), utrzymane zostały na tym poziomie do października 2008. Od listopada obserwujemy obniżanie stopy procentowej z poziomu $16,75 \%$ w październiku 2008 do $6,5 \% \mathrm{w}$ listopadzie 2009. Jednocześnie obserwujemy obniżanie się poziomu inflacji z 12\% (październik 2008) do 5,1\% (październik 2009), co jest zjawiskiem niestandardowym, zważywszy na jednoczesne obniżanie stóp procentowych (które było dość radykalne). Obniżanie stopy procentowej mogło być odpowiedzią na przedłużającą się w kraju recesję (recesja związana ze światowym kryzysem trwała w Turcji cztery kwartały). W styczniu 2009 roku został również podwyższony cel inflacyjny do poziomu 7,5\%, co oznaczało, że w kolejnych miesiącach inflacja znajdowała się blisko celu, a nawet poniżej niego. W styczniu 2012 celem inflacyjnym ustanowiono inflację na poziomie 5\%. Cel ten nie został zmieniony do końca omawianego okresu.

Kolejna recesja wystąpiła w Turcji w III i IV kwartale 2018 roku. Stopa procentowa od listopada 2016 roku pozostawała do maja 2018 na stałym poziomie wynoszącym $8 \%$. Natomiast inflacja w tym okresie podlegała wahaniom pomiędzy $7 \%$ a $13 \%$, ale daje się zauważyć tendencję oscylowania w okolicy $10 \%$. W czerw$\mathrm{cu}$, a więc tuż przez zidentyfikowaną recesją, bank centralny podjął decyzję o podwyższeniu stopy procentowej z 8\% w maju 2018 do 17,75\% w czerwcu. W tym samym miesiącu można również zaobserwować najwyższą w badanym okresie stopę inflacji, wynoszącą 15,4\%. Inflacja zaczęła rosnąć, osiągając w październiku 2018 poziom $25,2 \%$, mimo że bank centralny we wrześniu 2018 powtórnie zdecydował się na podwyższenie stóp procentowych do poziomu $24 \%$. Stopy procentowe pozostawały na tym poziomie do czerwca 2019. Inflacja zareagowała na wysokie stopy procentowe i zaczęła maleć od listopada 2018, osiągając w czerwcu 2019 poziom $15,7 \%$. Od lipca rozpoczęło się obniżanie stóp procentowych, przez co w maju 2020 osiągnęły one poziom $8,25 \%$. Inflacja natomiast malała do października 2019 (do poziomu 8,6\%), a następnie wzrosła do poziomu 12,4\% w lutym 2020.

Można także zauważyć zmienność stopy procentowej, która odpowiada politycznemu cyklowi koniunkturalnemu. Świadczą o tym obniżki stopy procentowej, które mają miejsce od września 2007 roku, w sierpniu 2011 roku (po wyborach w lipcu) oraz przed wyborami prezydenckimi w 2014 roku. W czasie dwóch pierwszych obniżek podczas wyborów parlamentarnych premierem był Recep Tayyip Erdoğan, który w wyborach w 2014 roku został prezydentem. Aby walczyć z inflacją, wzrastającą już od pierwszego kwartału (i zrealizować swój cel inflacyjny), bank centralny podwyższył podstawową stopę procentową z 8\% w maju 2018 do 17,75\% w czerwcu 2018, a później podwyższył ją ponownie z 17,75\% w sierpniu 
2018 do 24\% we wrześniu 2018. Spotkało się to jednak z wrogim nastawieniem prezydenta, który oczekiwał obniżenia stopy procentowej ze względu na recesję w III i IV kwartale 2018 roku. Gubernator banku centralnego został w 2019 roku odwołany bez podania przyczyny, a wkrótce po powołaniu nowego rozpoczęło się obniżanie stóp procentowych (z 24\% w czerwcu 2019 do 8,25\% w maju 2020).

Kolejnym wskaźnikiem, na który należy zwrócić uwagę, jest dynamika wolumenu wartości kredytów udzielonych sektorowi prywatnemu i jego związek $\mathrm{z}$ występowaniem w Turcji recesji (rysunek 5).

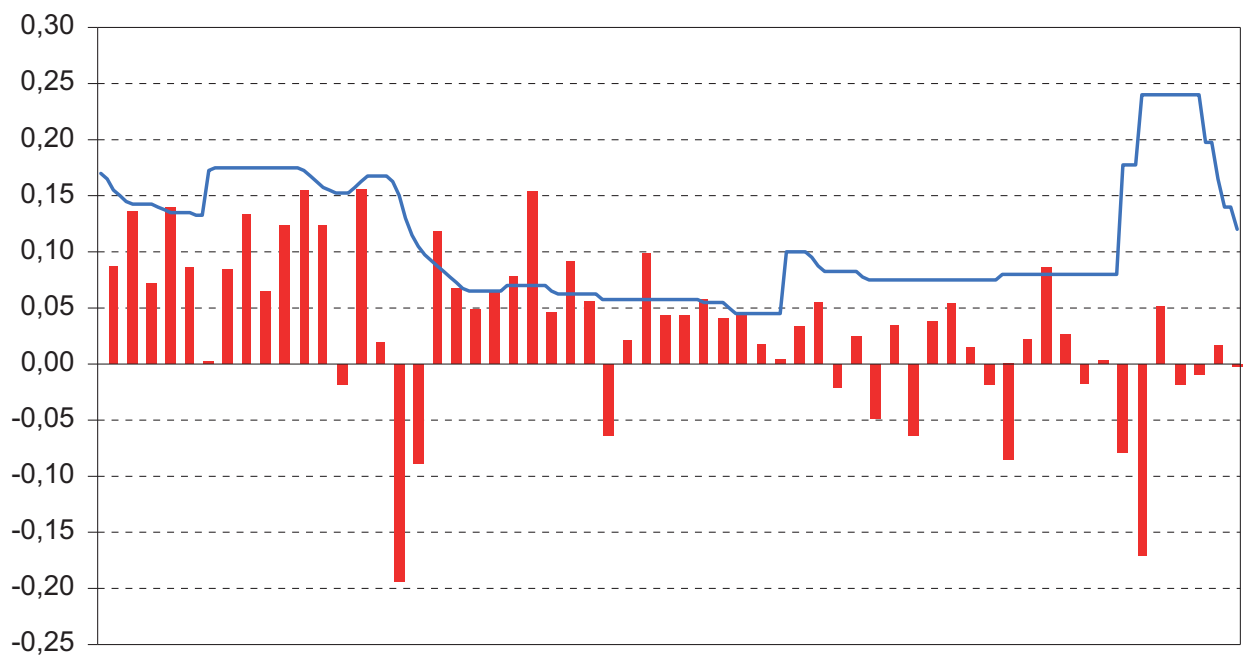

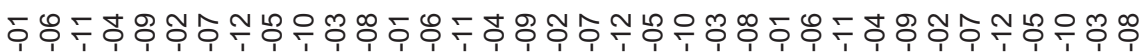

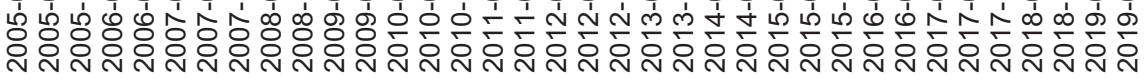

- dynamika wolumenu kredytów (qoq, \%) — podstawowa stopa procentowa (\%)

Rysunek 5. Poziom podstawowej stopy procentowej (\%) i dynamika wolumenu wartości kredytów udzielonych sektorowi prywatnemu (kwartał do kwartału, \%)

Źródło: Bank for International Settlements.

Pierwsza ze zidentyfikowanych recesji (II, III kwartał 2007) nie spowodowała zmniejszenia dynamiki wolumenu wartości kredytów udzielanych sektorowi prywatnemu. Można uznać, że banki w II kwartale 2007, w którym po raz pierwszy pojawiła się ujemna dynamika realnego PKB nie ograniczyły swojej akcji kredytowej przypuszczając, że mają do czynienia z jednokwartalnym spowolnieniem. W III kwartale dalej prowadziły zwiększoną akcję kredytową, jednakże ujemna dynamika realnego PKB utrzymująca się kolejny kwartał spowodowała, że w następnym okresie dynamika wolumenu wartości kredytów była mniejsza (chociaż bank centralny rozpoczął obniżanie stóp procentowych), ale wciąż dodatnia. W I kwartale 2008 roku mamy już do czynienia z ujemną dynamiką wo- 
lumenu wartości udzielanych kredytów, mimo że stopa procentowa jest niższa niż dwa kwartały wcześniej. Banki ograniczyły jednak podaż pieniądza w obawie przed utrzymującą się recesją. W IV kwartale 2007 roku i I kwartale 2008 roku obserwujemy dodatnią dynamikę realnego PKB, co sprawia, że banki ponownie decydują się na zwiększanie akcji kredytowej (tym bardziej, że sprzyja temu niższa stopa procentowa). Okazuje się jednak, że w kwartale, w którym dynamika wolumenu wartości udzielanych kredytów ponownie jest dodatnia i wysoka, rozpoczyna się recesja, a bank centralny decyduje się na podwyższanie podstawowej stopy procentowej. Banki, nauczone doświadczeniem wcześniejszej recesji, ograniczają akcję kredytową, ale dynamika wciąż jest dodatnia. W kolejnych kwartałach (VI kwartał 2008 roku i I kwartał 2009 roku) dynamika wolumenu wartości kredytów jest ujemna (znacznie bardziej niż w przypadku pierwszej recesji). Dodatnią dynamikę wolumenu wartości udzielanych kredytów można zaobserwować dopiero w II kwartale 2009 roku, co może być spowodowane zarówno zakończeniem się recesji, jak relatywnie niską stopą procentową. W okresie poprzedzającym trzecią zidentyfikowaną recesję dynamika wolumenu wartości kredytów była ujemna w IV kwartale 2017 roku i nieznacznie dodatnia w I kwartale 2018 roku. Trudno wyjaśnić to zjawisko, gdyż stopa procentowa nie była wówczas na wysokim (z perspektywy całego horyzontu czasowego) poziomie. Wystąpienie recesji w III i IV kwartale 2018 roku zbiegło się w czasie ze znacznymi podwyżkami stóp procentowych. Dynamika wolumenu wartości kredytów była wówczas ujemna.

Równie ważny jest odsetek kredytów zagrożonych niespłacalnością (rysunek 6).

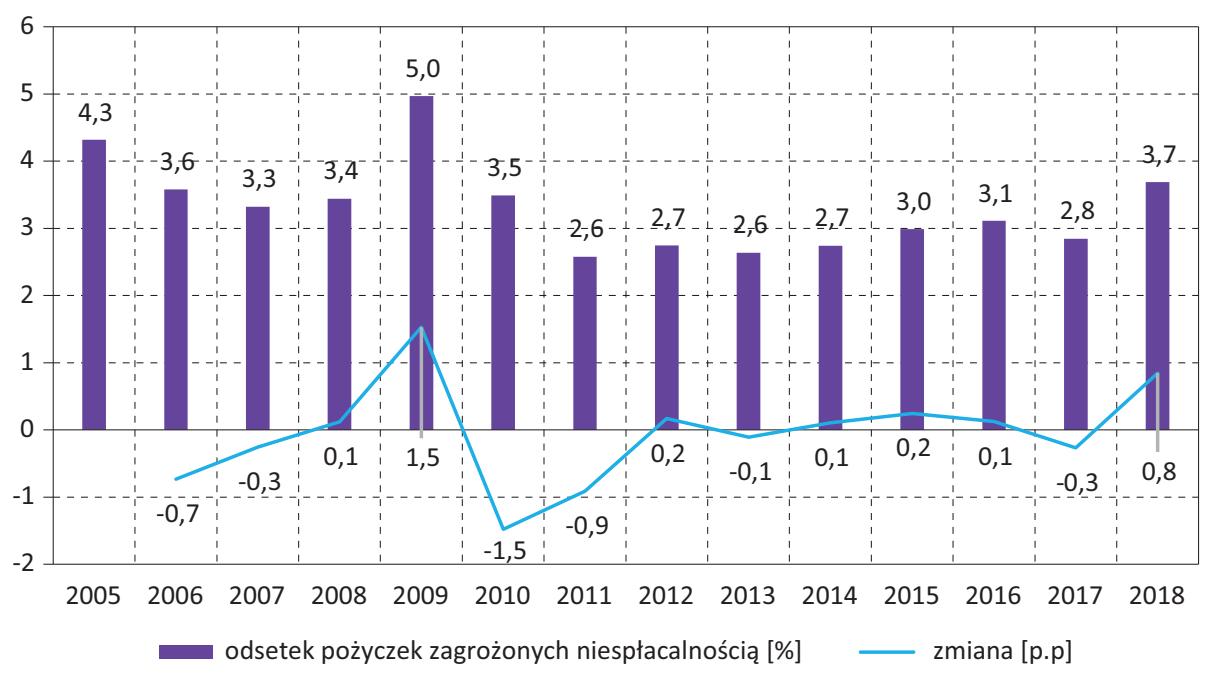

Rysunek 6. Odsetek kredytów zagrożonych niespłacalnością (w ogóle udzielonych kredytów, dane roczne, [\%]) i jego dynamika (pkt. proc.)

Źródło: IMF. 
Od 2005 roku odsetek kredytów zagrożonych niespłacalnością malał, aż do roku 2007, kiedy to w kwartałach II i III wystąpiła recesja. Ciekawe jest to, że można zaobserwować wzrost odsetka pożyczek zagrożonych niespłacalnością z poziomu 3,3\% do poziomu 3,4\% w roku 2008, a następnie do poziomu 5\% w 2009 roku (a więc w latach najdłuższej recesji w badanym okresie). Warto odnotować, że poziom z 2009 roku jest najwyższy w analizowanym horyzoncie czasowym. W kolejnych latach obserwujemy spadek odsetka do poziomu 2,6\% i jego utrzymywanie się na stabilnym poziomie (oscylującym wokół 3\%) do 2017 roku. W roku 2018, a więc w czasie ostatniej zidentyfikowanej recesji, zaobserwować można wzrost odsetka pożyczek zagrożonych niespłacalnością o 0,9 punktu procentowego w porównaniu do roku poprzedniego.

Ostatnim wskaźnikiem, który zostanie przeanalizowany, będą zmiany poziomu indeksu cen dla dóbr pośrednich, kapitałowych, konsumpcyjnych oraz surowców naturalnych i kopalin (rysunek 7). Zmiany poziomów cen zachodzące na poszczególnych etapach w strukturze produkcji są podstawowym wskaźnikiem wykorzystywanym w identyfikacji faz cyklu koniunkturalnego w ASE.

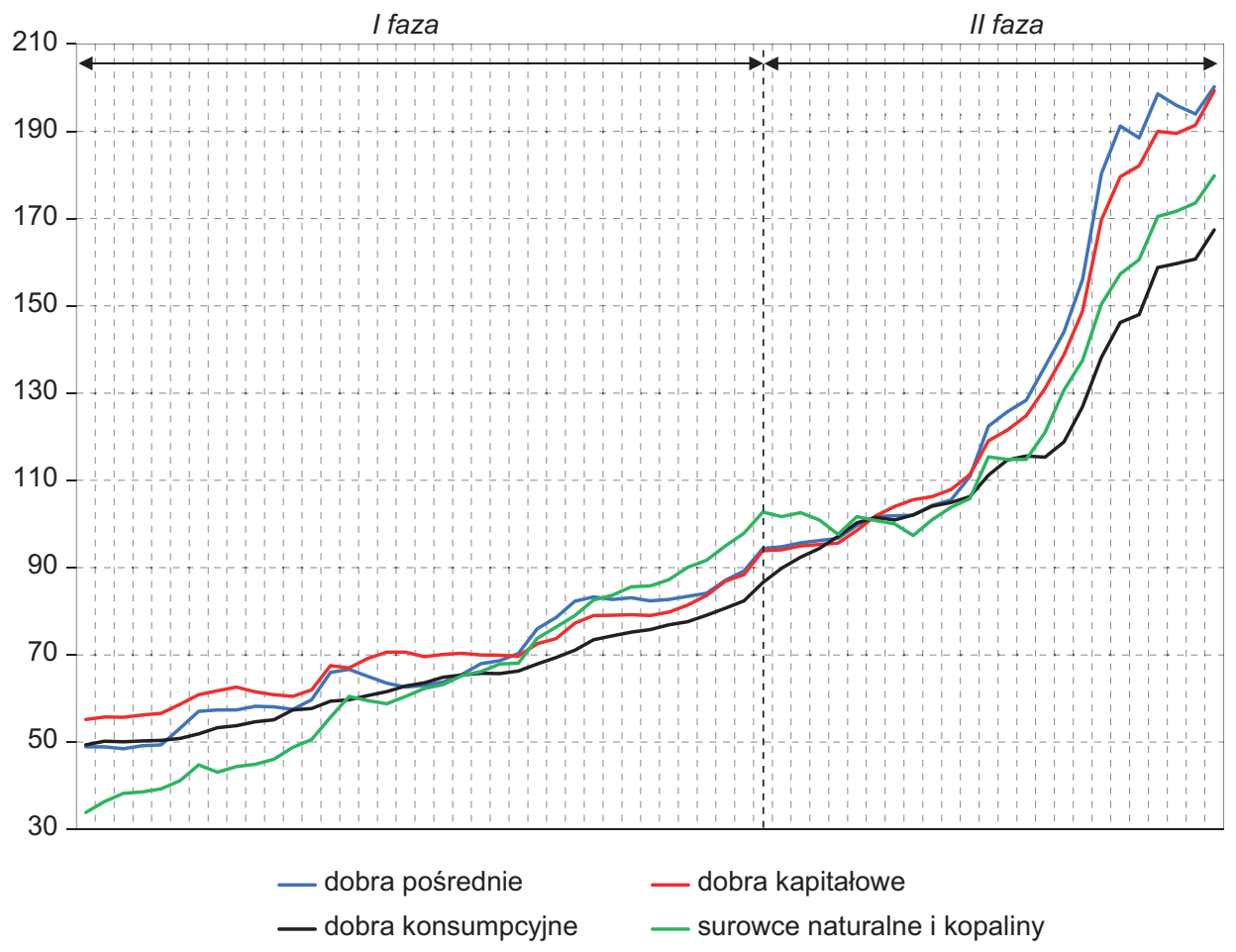

Rysunek 7. Indeksy cen dla poszczególnych typów dóbr (dane kwartalne, $2015=100$ ) Źródło: Eurostat. 
W I kwartale 2005, od którego rozpoczęta została analiza można zaobserwować, że największa różnica w indeksie cen dotyczy surowców naturalnych i kopalin (najniższy poziom) i dóbr kapitałowych (najwyższy poziom). Ceny surowców rosną jednak znacznie szybciej niż pozostałych dóbr, gdyż w I kwartale 2011 roku doganiają one dynamikę wzrostu cen dóbr kapitałowych. Rok później, w I kwartale 2012 roku, indeks ten wznosi się na najwyższy (spośród wszystkich indeksów) poziom. Do I kwartału 2014 widać, że ceny kształtują się zupełnie inaczej — najwyższy poziom osiągają ceny surowców i kopalin, zaś dóbr pośrednich i kapitałowych się zrównują. Najniższy poziom osiąga indeks cen dóbr konsumpcyjnych. Od II kwartału 2014 roku obserwujemy spadek indeksu cen surowców i kopalin, który w I kwartale 2016 roku ponownie znajduje się poniżej wszystkich pozostałych indeksów, ale powtórnie zaczyna rosnąć już od kolejnego kwartału. W okresie od II kwartału 2014 roku do I kwartału 2020 roku możemy zaobserwować, że największe wartości (od IV kwartału 2016) osiąga indeks cen dóbr pośrednich, a drugi w kolejności utrzymuje się indeks dóbr kapitałowych — oba te indeksy są indeksami cen dóbr wyższych rzędów. Od III kwartału 2017 roku obserwujemy również, że indeks cen dóbr konsumpcyjnych stale przyjmuje niższe wartości niż pozostałe indeksy. Tendencja ta utrzymuje się do I kwartału 2020, chociaż od IV kwartału 2018 roku widać większe wahania indeksu cen dóbr pośrednich.

\section{Identyfikacja cyklu}

Na podstawie analizy danych statystycznych w omawianym okresie można wnioskować, że gospodarka turecka znajdowała się w pierwszej i drugiej fazie cyklu koniunkturalnego według teorii ASE. Oznacza to, że w najbliższej przyszłości Turcja przejdzie do trzeciej fazy cyklu.

Cykl zidentyfikować można na podstawie zmian poziomów indeksów cen dla poszczególnych typów dóbr - dóbr pośrednich, kapitałowych, konsumpcyjnych oraz surowców naturalnych i kopalin (tabela 1).

Tabela 1. Zmiana poziomów cen w zidentyfikowanych fazach cyklu koniunkturalnego

\begin{tabular}{|c|c|c|c|c|c|c|}
\cline { 4 - 7 } \multicolumn{2}{l|}{} & \multicolumn{4}{|c|}{ zmiana indeksu cen (w pkt. proc.) } \\
\hline faza & początek & koniec & $\begin{array}{c}\text { surowce natu- } \\
\text { ralne i kopa- } \\
\text { liny }\end{array}$ & $\begin{array}{c}\text { dobra kapita- } \\
\text { łowe }\end{array}$ & $\begin{array}{c}\text { dobra pośred- } \\
\text { nie }\end{array}$ & $\begin{array}{c}\text { dobra kon- } \\
\text { sumpcyjne }\end{array}$ \\
\hline I & Q1-2005 & Q1-2014 & 68,8 & 38,7 & 45,5 & 37,2 \\
\hline II & Q2-2014 & Q1-2020 & 77,1 & 105,4 & 105,8 & 80,8 \\
\hline
\end{tabular}

Źródło: opracowanie własne na podstawie danych Eurostatu.

Pierwsza faza została zidentyfikowana od początku omawianego okresu (I kwartał 2005) do I kwartału 2014. W tej fazie możemy zauważyć największy 
wzrost cen surowców naturalnych i kopalin (indeks cen wzrósł o 68,8 punktów procentowych). W drugiej kolejności (pod względem wzrostu cen) możemy zaobserwować wzrost cen dóbr wyższych rzędów - a więc dóbr pośrednich (o 45,5 punktów procentowych) oraz dóbr kapitałowych (o 38,7 punktów procentowych). Najmniej wzrosły ceny dóbr konsumpcyjnych (o 37,2 punktów procentowych). Od II kwartału 2014 roku sytuacja zaczyna się zmieniać. W okresie od II kwartału 2014 do końca omawianego okresu można zauważyć, że w największym stopniu przyrastają ceny dóbr wyższych rzędów - dóbr pośrednich (wzrost indeksu o 105,8 punktów procentowych) i dóbr kapitałowych (wzrost o 105,4 punkty procentowe). W następnej kolejności pod względem wzrostu możemy zaobserwować zmianę poziomu cen dóbr konsumpcyjnych (wzrost indeksu o 80,8 punktów procentowych). Najmniej zmieniają się ceny surowców naturalnych (o 77,1 punktów procentowych), które wzrastały w pierwszej fazie. Zmienność indeksów cen w obu fazach jest w pełni zgodna $\mathrm{z}$ austriacką teorią cyklu.

Aby potwierdzić występowanie faz cyklu, omówione zostaną jeszcze zmiany indeksu PPI w sektorze wydobywczym i sektorze przetwórstwa przemysłowego (rysunek 8). Indeks PPI w sektorze wydobywczym na początku badanego okresu znajduje się poniżej indeksu PPI w sektorze przetwórstwa przemysłowego. Jest od niego niższy, ale rośnie szybciej i osiąga podobny poziom do indeksu PPI w sektorze przetwórstwa przemysłowego w IV kwartale 2010 roku. W II kwartale 2014

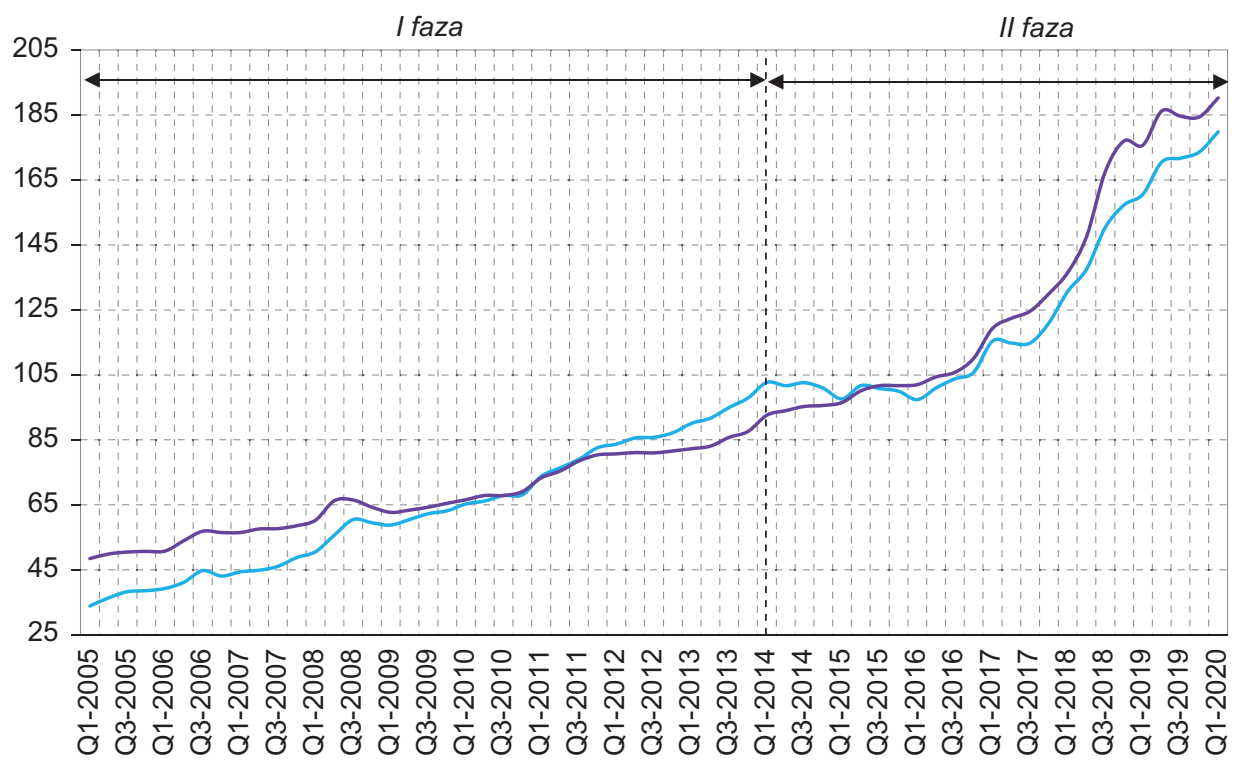

— górnictwo i wydobycie — przetwórstwo przemysłowe

Rysunek 8. Zmiana indeksu PPI w sektorze wydobywczym oraz w sektorze przetwórstwa przemysłowego

Źródło: Eurostat. 
roku, a więc wtedy, gdy rozpoczęła się zidentyfikowana II faza cyklu koniunkturalnego, indeks PPI w sektorze wydobywczym był wyższy niż w sektorze przetwórstwa przemysłowego. Od II kwartału 2014 roku możemy zaobserwować spadek indeksu PPI (do I kwartału 2016 roku), podczas gdy indeks PPI przetwórstwa przemysłowego ciągle rośnie (większe wahania pojawiają się dopiero od I kwartału 2019). W III kwartale 2015 roku indeks PPI w przetwórstwie przemysłowym osiąga wyższy poziom od indeksu PPI w sektorze wydobywczym i utrzymuje się na wyższym poziomie do końca analizowanego okresu.

W pierwszej fazie cyklu największą zmianę obserwujemy w sektorze wydobywczym (tabela 2). Od I kwartału 2005 do I kwartału 2014 roku indeks PPI wzrósł o 68,8 punktów procentowych. Zmiana indeksu PPI w sektorze przetwórstwa przemysłowego wynosiła 44,1 punktu procentowego. W drugiej fazie cyklu większą zmianę w indeksie PPI można zaobserwować w indeksie PPI sektora przetwórstwa przemysłowego. Pomiędzy II kwartałem 2014 a I kwartałem 2020 indeks PPI w sektorze wydobywczym wzrósł o 77,1 punktu procentowego, natomiast w sektorze przetwórstwa przemysłowego o 97,6 punktu procentowego.

Tabela 2. Zmiana indeksu PPI w zidentyfikowanych fazach cyklu koniunkturalnego

\begin{tabular}{|c|c|c|c|c|}
\cline { 3 - 5 } \multicolumn{2}{c|}{} & \multicolumn{2}{c|}{ zmiana indeksu PPI (w pkt. proc.) } \\
\hline faza & początek & koniec & sektor wydobywczy & sektor przetwórstwa przemysłowego \\
\hline I & Q1-2005 & Q1-2014 & 68,8 & 44,1 \\
\hline II & Q2-2014 & Q1-2020 & 77,1 & 97,6 \\
\hline
\end{tabular}

Źródło: opracowanie własne na podstawie danych Eurostatu.

\section{Wnioski}

Zgodnie z klasyczną definicją recesji, Turcja została nią dotknięta trzykrotnie — w roku 2007 (II i III kwartał), w latach 2008-2009 (II, III i IV kwartał 2008 oraz I kwartał 2009) oraz w roku 2018 (III i IV kwartał). Świadczy o tym ujemna dynamika realnego PKB utrzymująca się przez co najmniej dwa kwartały z rzędu. Recesja, na którą wskazuje ekonomia głównego nurtu, nie znajduje jednak potwierdzenia $\mathrm{w}$ analizie danych empirycznych przeprowadzonej według metodologii ASE. Wskazuje to na znaczne trudności z aplikacyjnym zastosowaniem austriackiej teorii cyklu koniunkturalnego, jednak w żaden sposób nie podważa zasadności stosowania takiego ujęcia. Zgodnie z ekonomią głównego nurtu w fazie recesji można wyróżnić dwa podokresy, które cechują się odmienną tendencją w zakresie dynamiki cen - w pierwszym podokresie ceny wciąż wzrastają, jednak z malejącą dynamiką; w drugim - ceny maleją (dynamika zmian jest ujemna). Na tym tle zmiany cen opisywane austriacką teorią cyklu wprawdzie wydają się być dokładniejszym opisem zmian zachodzących w cyklu (zwłaszcza 
w czasowej strukturze produkcji), jednak wykorzystanie ich jako jedynego miernika opisującego cykl wydaje się być dyskusyjne. Można bowiem tak, jak miało to miejsce w przypadku Turcji, zaobserwować, że okres kryzysu 2007-2009 (na który wskazuje klasyczna definicja recesji) jest jednocześnie okresem fazy wzrostowej według austriackiej teorii cyklu. Tę niespójność można wyjaśnić jedynie, odwołując się do zmian wywoływanych na rynku pieniężnym przez interwencję banku centralnego. Tylko w ten sposób da się w kompleksowy sposób opisywać zmiany zachodzące $\mathrm{w}$ gospodarce. Zmiany te $\mathrm{w}$ sferze realnej mogą do pewnego stopnia zostać utajone za pomocą zmian w sferze nominalnej, które zachodzą w następstwie dyskrecjonalnej interwencji rządu i/lub banku centralnego. Właśnie taki mechanizm - i swoistą pozorną sprzecznością w wyodrębnianiu faz cyklu — można zidentyfikować w Turcji.

W kraju tym, mającym za sobą wieloletnie epizody wysokiej inflacji, wykorzystanie podstawowej stopy procentowej jako narzędzia wychodzenia z recesji jest ograniczone, gdyż podstawowym celem banku centralnego jest utrzymanie inflacji możliwie blisko celu inflacyjnego. Dopiero w momencie, gdy inflacja jest opanowana, bank centralny może wspierać rząd w procesie wzrostu. Pewnymi wyjątkami zaobserwowanymi podczas analizy danych są okres okołowyborczy, w którym można zauważyć mechanizm politycznego cyklu koniunkturalnego, oraz rok 2019, kiedy to po odwołaniu gubernatora banku centralnego stopy procentowe obniżano (mimo wysokiej, choć spadającej inflacji).

W omawianym okresie można zidentyfikować dwie fazy cyklu koniunkturalnego, zgodnego z założeniami austriackiej szkoły ekonomii. Faza pierwsza trwała od I kwartału 2005 (od początku omawianego okresu) do I kwartału 2014 roku, o czym świadczy największy wzrost indeksu cen surowców i kopalin przy jednoczesnym najmniejszym wzroście cen dóbr konsumpcyjnych. Faza druga trwała od II kwartału 2014 roku do I kwartału 2020 (a więc ostatniego, dla którego dostępne są dane). Świadczy o niej największa zmiana indeksu cen dóbr wyższego rzędu — kapitałowych i dóbr pośrednich, oraz spadek wzrostu cen kopalin. Gospodarka nie weszła jeszcze w fazę trzecią, gdyż w tej fazie najszybciej powinny wzrastać ceny dóbr konsumpcyjnych. Da się jednak zauważyć większe wahania cen dóbr wyższych rzędów od IV kwartału 2018 roku — to może zwiastować ich spadek, któremu towarzyszyć będzie wzrastająca dynamika cen dóbr konsumpcyjnych. Trudno jednak ocenić, kiedy gospodarka może wejść w trzecią fazę, zwłaszcza że pojawiło się widmo recesji związanej z pandemią COVID-19.

\section{Bibliografia}

Bank Centralny Republiki Turcji. (2012). The Central Bank of the Republic of Turkey: From Past to Present. Ankara.

Garrison, R. (2001). Time and Money: The Macroeconomics of Capital Structure. New York: Routledge. 
Hayek, F.A. von. (1931 [2014]). Ceny i produkcja. W: F.A. Hayek, Pieniadz i kryzysy. Dzieła wybrane, t. 1. Warszawa: Instytut Ludwiga von Misesa.

Huerta de Soto, J. (2010). Szkoła austriacka. Ład rynkowy, wolna wymiana i przedsiębiorczość. Warszawa: Fijor Publishing.

Huerta de Soto, J. (2011). Pieniadz, kredyt bankowy i cykle koniunkturalne. Warszawa: Instytut Ludwiga von Misesa.

Mises, L. (2011). Ludzkie działanie. Traktat o ekonomii. Warszawa: Instytut Ludwiga von Misesa.

Rothbard, M.N. (2007). Tajniki bankowości. Podręcznik akademicki. Warszawa: Fijorr Publishing. Rothbard, M.N. (2008). Ekonomia wolnego rynku, t. 3. Warszawa: Fijorr Publishing.

Rothbard, M.N. (2010). Wielki kryzys w Ameryce. Warszawa: Instytut Ludwika von Misesa.

Skousen, M. (2011). Struktura produkcji. Giełda, kapitat, konsumpcja. Warszawa: Fijorr Publishing.

\section{Źródła danych}

Bank for International Settlements. Data dostępu: 1.06.2021, https://www.bis.org/.

Bank Centralny Republiki Turcji. Data dostępu: 30.05.2021, https://tcmb.gov.tr/.

Eurostat. Data dostępu: 5.06.2021, https://ec.europa.eu/eurostat.

IMF. Data dostępu: 30.05.2021, https://www.imf.org/external/index.htm.

OECD. Data dostępu: 1.06.2021, https://www.oecd.org/. 